\title{
Effects of Asian Sand Dust on Respiratory Health
}

\section{Cui Hua Liu*}

CAS Key Laboratory of Pathogenic Microbiology and Immunology, Institute of Microbiology, Chinese Academy of Sciences, China

The Asian Sand Dust (ASD) aerosol spreads over large areas, including East China, the Korean Peninsula, Japan and the United States [1]. ASD contains a variety of chemical species, such as Sulfate $\left(\mathrm{SO}_{4}^{2-}\right)$ and Nitrate $\left(\mathrm{NO}_{3}^{-}\right)$derived from air pollutants $\left(\mathrm{SO}_{2}, \mathrm{NO}_{2}\right)$, as well as microbial agents, such as bacteria, fungi, and viruses [2,3]. About $53 \%$ to $71 \%$ of the pollutants in ASD are of less than $10 \mathrm{~mm}$ in diameter (PM10), and those particles can reach the lower respiratory tract, causing inflammatory and allergic diseases. Therefore, hazardous effects of ASD aerosol on human respiratory health are becoming a serious concern in China and neighboring countries.

Since ASD adsorbs many kinds of microorganisms including highly pathogenic bacteria or viruses, it may result in exacerbation of pneumonia by the pathogens. Indeed, epidemiologic studies have demonstrated that dust storm events caused an increase of hospitalization for pneumonia in China [4]. Studies have shown that intratracheal instillation of ASD caused bronchitis and alveolitis, whereas ASD heated at $360^{\circ} \mathrm{C}$ (to exclude toxic materials such as microbiological materials, etc.) caused considerably fewer effects [5]. These results suggest that the microbial components attached to ASD play an important role in the lung inflammation caused by ASD. Another study further demonstrated that administration of ASD exacerbates pneumonia incidence in Klebsiella pneumoniae infected mice, which is evidenced by cellular profiles of BALF and pathological examinations [6].

ASD has also been associated with allergic diseases. For example, there are several reports on the exacerbation of Japanese cedar pollinosis and seasonal allergic rhinitis as well as of adult and child asthma occurring during dust storm events $[7,8]$. Results from a study demonstrated that the mineralogical components of ASD particles, free from chemical and biological pollutants, caused acute inflammatory changes in the lung tissue and BALF in vivo [9]. Another study suggests that ASD can aggravate airway disease by activating inflammatory reactions through increased mucus secretion [10].
In conclusion, atmospheric exposure to sand dust containing pathogens as well as mineralogical components could present a significant threat to human respiratory health. Thus, enforcement of air quality regulations should be strengthened in both China and other countries in order to prevent further deterioration of the already devastating ASD.

\section{References}

1. Duce RA, Unni CK, Ray BJ, Prospero JM, Merrill JT (1980) Long-range atmospheric transport of soil dust from Asia to the tropical north pacific: temporal variability. Science 209: 1522-1524.

2. Chen PS, Tsai FT, Lin CK, Yang CY, Chan CC, et al. (2010) Ambient influenza and avian influenza virus during dust storm days and background days. Environ Health Perspect 118: 1211-1216.

3. Maki T, Susuki S, Kobayashi F, Kakikawa M, Tobo Y, et al. (2010) Phylogenetic analysis of atmospheric halotolerant bacterial communities at high altitude in an Asian dust (KOSA) arrival region, Suzu City. Sci Total Environ 408: 4556-4562.

4. Meng Z, Lu B (2007) Dust events as a risk factor for daily hospitalization for respiratory andcardiovascular diseases in Minqin. China Atmos Environ 41: 7048-7058.

5. He M, Ichinose T, Yoshida S, Nishikawa M, Mori I, et al. (2010) Airborne Asian sand dust enhances murine lung eosinophilia. Inhal Toxicol 22: 1012-1025.

6. He M, Ichinose T, Yoshida S, Yamamoto S, Inoue K, et al. (2012) Asian sand dust enhances murine lung inflammation caused by Klebsiella pneumoniae. Toxicol Appl Pharmacol 258: 237-247

7. Watanabe M, Yamasaki A, Burioka N, Kurai J, Yoneda K, et al. (2011) Correlation between Asian dust storms and worsening asthma in Western Japan. Allergol Int 60: 267-275.

8. Kanatani KT, Ito I, Al-Delaimy WK, Adachi Y, Mathews WC, et al. (2010) Desert dust exposure is associated with increased risk of asthma hospitalization in children. Am J Respir Crit Care Med 182: 1475-1481.

9. Naota M, Mukaiyama T, Shimada A, Yoshida A, Okajima M, et al. (2010) Pathological study of acute pulmonary toxicity induced by intratracheally instilled Asian sand dust (kosa). Toxicol Pathol 38: 1099-1110.

10. Jung JH, Kang IG, Cha HE, Choe SH, Kim ST (2012) Effect of Asian sand dust on mucin production in $\mathrm{NCl}-\mathrm{H} 292$ cells and allergic murine model. Otolaryngol Head Neck Surg 146: 887-894.
${ }^{*}$ Corresponding author: Cui Hua Liu, Associate Professor, CAS Key Laboratory of Pathogenic Microbiology and Immunology, Institute of microbiology, Chinese Academy of Sciences, Room A216, NO.8 North 2 Zhongguancun Road, Haidian District, Beijing 100190, China, Tel: 86-10-62554387; E-mail: liucuihua@im.ac.cn

Received May 20, 2013; Accepted May 21, 2013; Published May 23, 2013

Citation: Liu CH (2013) Effects of Asian Sand Dust on Respiratory Health. J Pulm Respir Med 3: e125. doi:10.4172/2161-105X. 1000e125

Copyright: (C) $2013 \mathrm{Liu} \mathrm{CH}$. This is an open-access article distributed under the terms of the Creative Commons Attribution License, which permits unrestricted use, distribution, and reproduction in any medium, provided the original author and source are credited. 